\title{
Front Matter: Volume 10388
}

, "Front Matter: Volume 10388," Proc. SPIE 10388, Advances in Computational Methods for X-Ray Optics IV, 1038801 (25 October 2017); doi: $10.1117 / 12.2295995$

SPIE Event: SPIE Optical Engineering + Applications, 2017, San Diego, California, SPIE. United States 


\section{PROCEEDINGS OF SPIE}

\section{Advances in Computational Methods for X-Ray Optics IV}

Oleg Chubar

Kawal Sawhney

Editors

9-10 August 2017

San Diego, California, United States

Sponsored by

SPIE

Cosponsored by

RadiaSoft (United States)

Published by

SPIE

Volume 10388 
The papers in this volume were part of the technical conference cited on the cover and title page. Papers were selected and subject to review by the editors and conference program committee. Some conference presentations may not be available for publication. Additional papers and presentation recordings may be available online in the SPIE Digital Library at SPIEDigitalLibrary.org.

The papers reflect the work and thoughts of the authors and are published herein as submitted. The publisher is not responsible for the validity of the information or for any outcomes resulting from reliance thereon.

Please use the following format to cite material from these proceedings:

Author(s), "Title of Paper," in Advances in Computational Methods for X-Ray Optics IV, edited by Oleg Chubar, Kawal Sawhney, Proceedings of SPIE Vol. 10388 (SPIE, Bellingham, WA, 2017) Sevendigit Article CID Number.

ISSN: 0277-786X

ISSN: 1996-756X (electronic)

ISBN: 9781510612334

ISBN: 9781510612341 (electronic)

Published by

SPIE

P.O. Box 10, Bellingham, Washington 98227-0010 USA

Telephone +1 3606763290 (Pacific Time) · Fax +1 3606471445

SPIE.org

Copyright (c) 2017, Society of Photo-Optical Instrumentation Engineers.

Copying of material in this book for internal or personal use, or for the internal or personal use of specific clients, beyond the fair use provisions granted by the U.S. Copyright Law is authorized by SPIE subject to payment of copying fees. The Transactional Reporting Service base fee for this volume is $\$ 18.00$ per article (or portion thereof), which should be paid directly to the Copyright Clearance Center (CCC), 222 Rosewood Drive, Danvers, MA 01923. Payment may also be made electronically through CCC Online at copyright.com. Other copying for republication, resale, advertising or promotion, or any form of systematic or multiple reproduction of any material in this book is prohibited except with permission in writing from the publisher. The CCC fee code is 0277$786 \mathrm{X} / 17 / \$ 18.00$.

Printed in the United States of America.

Publication of record for individual papers is online in the SPIE Digital Library.

\section{SPIE. DIGITAL}

Paper Numbering: Proceedings of SPIE follow an e-First publication model. A unique citation identifier (CID) number is assigned to each article at the time of publication. Utilization of CIDs allows articles to be fully citable as soon as they are published online, and connects the same identifier to all online and print versions of the publication. SPIE uses a seven-digit CID article numbering system structured as follows:

- The first five digits correspond to the SPIE volume number.

- The last two digits indicate publication order within the volume using a Base 36 numbering system employing both numerals and letters. These two-number sets start with $00,01,02,03$, 04, 05, 06, 07, 08, 09, 0A, OB ... 0Z, followed by 10-1Z, 20-2Z, etc. The CID Number appears on each page of the manuscript. 


\title{
Contents
}

\author{
$\checkmark$ Authors \\ vii Conference Committee
}

COMPUTER CODES: OVERVIEWS, METHODS, AND APPLICATIONS I

1038804 Recent progress of the synchrotron radiation code SPECTRA (Invited Paper) [10388-4]

1038805 Main functions, recent updates, and applications of Synchrotron Radiation Workshop code (Invited Paper) [10388-5]

\section{COMPUTER CODES: OVERVIEWS, METHODS, AND APPLICATIONS II}

1038808 Interoperability and complementarity of simulation tools for beamline design in the OASYS environment (Invited Paper) [10388-8]

1038809 McXtrace 1.4: latest developments in the new release [10388-9]

\section{NEW INSTRUMENTS AND BEAMLINES}

10388 OC X-ray optics simulation and beamline design for the APS upgrade (Invited Paper) [10388-12]

10388 OD Simulation and optimization of the SIRIUS IPE soft $x$-ray beamline [10388-13]

10388 OE Optical design and simulation of a new coherence beamline at NSLS-II [10388-14]

\section{X-RAY OPTICS: SIMULATION, DEVELOPMENT, AND METROLOGY I}

10388 OG Effect of $x$-ray mirror figure error on the focus profile: comparison of measurements with physical and geometric optics simulations (Invited Paper) [10388-16]

10388 ol Speckle-based at-wavelength metrology of x-ray optics at Diamond Light Source (Invited Paper) [10388-18]

10388 OJ Stochastic analysis of 1D and 2D surface topography of $x$-ray mirrors [10388-19]

\section{X-RAY OPTICS: SIMULATION, DEVELOPMENT, AND METROLOGY II}

$10388 \mathrm{OL}$ Aberrations in compound refractive lens systems: analytical and numerical calculations [10388-21] 
$103880 \mathrm{M}$ Simulations of single-particle imaging of hydrated proteins with $\mathrm{x}$-ray free-electron lasers (Invited Paper) [10388-22]

10388 ON X-ray optical simulations supporting advanced commissioning of the coherent hard $x$-ray beamline at NSLS-II [10388-23]

10388 OP A Monte Carlo simulation of scattering reduction in spectral x-ray computed tomography [10388-25]

SOFTWARE DEMONSTRATION IN COMPUTATIONAL METHODS FOR X-RAY OPTICS

10388 OR Sirepo: a web-based interface for physical optics simulations - its deployment and use at NSLS-II (Invited Paper) [10388-27]

10388 OS OASYS (OrAnge SYnchrotron Suite): an open-source graphical environment for $x$-ray virtual experiments (Invited Paper) [10388-28]

POSTER SESSION

10388 OW Analysis on partial coherence propagation using the four-dimensional coherence function [10388-32]

10388 OX A fast and reliable approach to simulating the output from an x-ray tube used for developing security backscatter imaging [10388-33]

10388 OY Use of simulation to optimize the pinhole diameter and mask thickness for an $x$-ray backscatter imaging system [10388-34]

$10388 \mathrm{OZ}$ Alignment of KB mirrors with at-wavelength metrology tool simulated using SRW [10388-36]

1038811 Simulation of experiments with partially coherent x-rays using Synchrotron Radiation Workshop [10388-38] 


\section{Authors}

Numbers in the index correspond to the last two digits of the seven-digit citation identifier (CID) article numbering system used in Proceedings of SPIE. The first five digits reflect the volume number. Base 36 numbering is employed for the last two digits and indicates the order of articles within the volume. Numbers start with 00, 01, 02, 03, 04, 05, 06, 07, 08, 09, 0A, 0B...0Z, followed by 10-1Z, 20-2Z, etc.

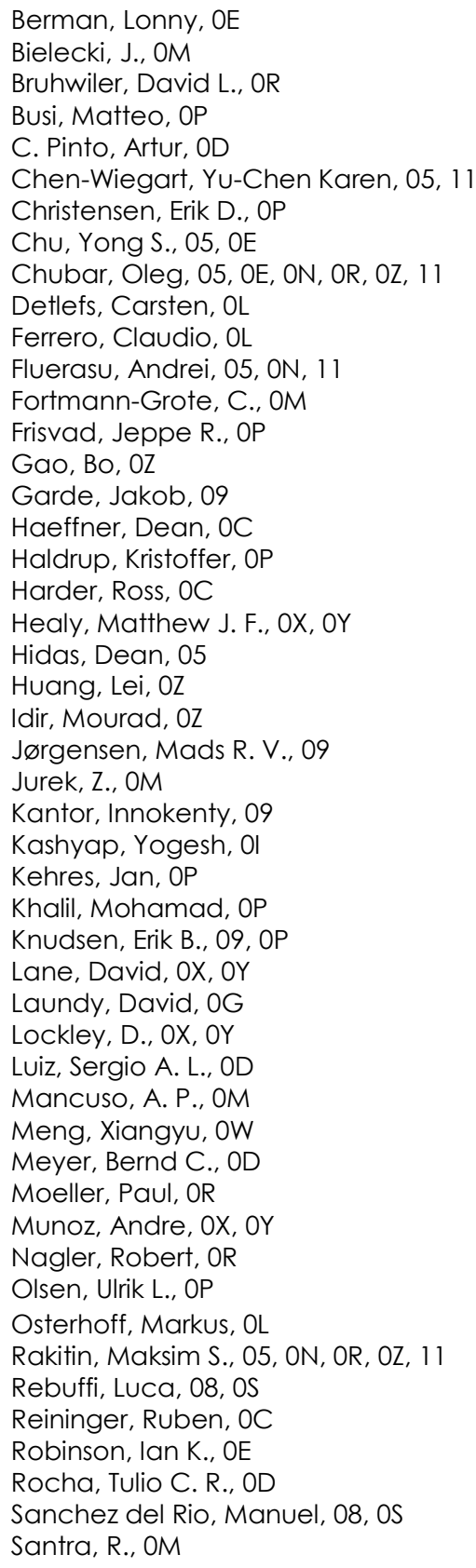

\author{
Sawhney, Kawal, 0G, 01 \\ Shi, Xianbo, OC \\ Tai, Renzhong, OW \\ Tanaka, Takashi, 04 \\ Tyurin, Yury N., OJ \\ Tyurina, Anastasia Y., OJ \\ Vella, A., OX, OY \\ Wang, Hongchang, 0 I \\ Wang, Yong, OW \\ Westfahl, Harry, OD \\ Wiegart, Lutz, 05, 0N, 11 \\ Willendrup, Peter K., 09 \\ Williams, Garth J., OE \\ Wu, Yanqing, OW \\ Xue, Chaofan, OW \\ Xue, Junpeng, $0 Z$ \\ Yashchuk, Valeriy V., OJ \\ Yu, Huaina, OW \\ Zhou, J., OX \\ Zhou, Tunhe, ol \\ Ziaja-Motyka, B., OM
}


Proc. of SPIE Vol. 10388 1038801-6

Downloaded From: https://www.spiedigitallibrary.org/conference-proceedings-of-spie on 26 Apr 2023 Terms of Use: https://www.spiedigitallibrary.org/terms-of-use 


\title{
Conference Committee
}

\author{
Conference Chairs
}

Oleg Chubar, Brookhaven National Laboratory (United States)

Kawal Sawhney, Diamond Light Source Ltd. (United Kingdom)

Conference Co-chairs

Manuel Sanchez del Rio, European Synchrotron Radiation Facility (France)

Carolyn MacDonald, University at Albany (United States)

Program Track Chairs

Ali M. Khounsary, Illinois Institute of Technology (United States)

Ralph B. James, Savannah River National Laboratory (United States)

\section{Conference Program Committee}

Lucia Alianelli, Diamond Light Source Ltd. (United Kingdom)

Johannes Bahrdt, Helmholtz-Zentrum Berlin für Materialien und Energie $\mathrm{GmbH}$ (Germany)

Edoardo Busetto, Elettra-Sincrotrone Trieste S.C.p.A. (Italy)

Roger J. Dejus, Argonne National Laboratory (United States)

Claudio Ferrero, ESRF - The European Synchrotron (France)

Gianluca Aldo Geloni, European XFEL GmbH (Germany)

Kenneth W. Hill, Princeton Plasma Physics Laboratory (United States)

Mourad Idir, Brookhaven National Laboratory (United States)

Tetsuya Ishikawa, RIKEN (Japan)

Ali M. Khounsary, Illinois Institute of Technology (United States) and X-ray Optics Inc. (United States)

Erik Bergbäck Knudsen, Technical University of Denmark (Denmark)

Jacek Krzywinski, SLAC National Accelerator Laboratory (United States)

Bernd C. Meyer, Laboratório Nacional de Luz Sincrotron (Brazil)

Giovanni Pareschi, INAF - Osservatorio Astronomico di Brera (Italy)

Ruben Y. Reininger, Brookhaven National Laboratory (United States) and Scientific Answers \& Solutions LLC (United States)

Liubov Samoylova, European XFEL GmbH (Germany)

Yuri V. Shvyd'ko, Argonne National Laboratory (United States) 
Peter C. Sondhauss, MAX IV Laboratory, Lund University (Sweden)

Timm Weitkamp, Synchrotron SOLEIL (France)

Garth J. Williams, Brookhaven National Laboratory (United States)

Valeriy V. Yashchuk, Lawrence Berkeley National Laboratory

(United States)

\section{Session Chairs}

1 Keynote Session

Oleg Chubar, Brookhaven National Laboratory (United States)

2 Computer Codes: Overviews, Methods, and Applications I

Tetsuya Ishikawa, RIKEN (Japan)

3 Computer Codes: Overviews, Methods, and Applications II

David Laundy, Diamond Light Source Ltd. (United Kingdom)

4 New Instruments and Beamlines

Qun Shen, Brookhaven National Laboratory (United States)

5 X-Ray Optics: Simulation, Development, and Metrology I

Franz Schaefers, Helmholtz-Zentrum Berlin für Materialien und Energie GmbH (Germany)

6 X-Ray Optics: Simulation, Development, and Metrology II

Yuri V. Shvyd'ko, Argonne National Laboratory (United States)

$7 \quad$ Simulation of Experiments and Data Processing

Jacek Krzywinski, SLAC National Accelerator Laboratory

(United States)

8 Software Demonstration in Computational Methods for X-Ray Optics Oleg Chubar, Brookhaven National Laboratory (United States) 